\title{
ПОРІВНЯЛЬНИЙ АНАЛІЗ ОСНОВНИХ ПОКАЗНИКІВ ЗАХВОРЮВАНОСТІ НАСЕЛЕННЯ ТЕРНОПІЛЬСЬКОЇ ОБЛАСТІ
}

\author{
ДВНЗ «Тернопільський державний медичний університет імені І.Я. Горбачевського МОЗ України»
}

\begin{abstract}
Мета: проаналізувати зміни в захворюваності населення Тернопільської області протягом 2009-2013 років.
Матеріали і методи. Спостереження здійснювалося як популяційне, епідеміологічне й охоплювало період з 2009 до 2013 року. Було проаналізовано статистичні довідники та статистичні дані щодо захворюваності населення області.
\end{abstract}

Результати. Встановлено, що загальний показник поширеності хвороб серед населення Тернопільської області формувався за рахунок хвороб системи кровообігу (32,7\%), органів дихання (20,7\%) та травлення (9,5\%). Структуру первинної захворюваності формували хвороби органів дихання (45,4\%), хвороби системи кровообігу (7,3\%), хвороби шкіри та підшкірної клітковини (6,9\%).

Висновки. Аналіз показників поширеності хвороб та первинної захворюваності протягом 2009-2013 років свідчить про негативні тенденції стану здоров'я населення. Відмічено зростання рівня поширеності хвороб протягом досліджуваного періоду та деяке зниження рівня первинної захворюваності.

КЛЮЧОВІ СЛОВА: захворюваність, поширеність хвороб, порівняльний аналіз.

Здоров'я населення займає особливе місце у системі цінностей цивілізованої країни. Здоров'я населення країни відображає ії соціально-економічне, екологічне, демографічне і санітарногігієнічне благополуччя, є одним із соціальних індикаторів суспільного прогресу, важливим чинником, який впливає на якість та ефективність трудових ресурсів.

Вивчення тенденцій захворюваності та поширеності хвороб серед населення є однією з важливих складових стратегічного планування медичної галузі.

Мета: проаналізувати зміни в захворюваності населення Тернопільської області протягом 20092013 років.

Матеріали і методи. Спостереження здійснювалося як популяційне, епідеміологічне й охоплювало період з 2009 до 2013 року. Було проаналізовано статистичні довідники та статистичні дані щодо захворюваності населення області.

Результати дослідження та їх обговорення. Захворюваність населення України має тенденцію до зростання. Особливо це стосується поширеності захворювань. Якщо у 1991 р. рівень поширеності становив 1104,0\%о, то в 2013 р. він зріс у 1,68 разу $(1856,5 \%$ o). Первинна захворюваність зростала не такими стрімкими темпами лише в 1,1 разу (відповідно, 620,0\%о та 683,8\%о).

Нами проведено порівняльний аналіз показників поширеності та первинної захворюваності серед населення Тернопільської області. Виявлено, що рівні поширеності захворювань у пері-

(C) В.Л. Смірнова, Н.Я. Панчишин, 2014 од 2009-2013 рр. загалом мали тенденцію до зростання. Аналіз показників поширеності захворювань серед всього населення України показує, що у період 2009-2011 рр. спостерігалось їх зростання, а в 2012 та 2013 рр. - зниження (табл. 1).

Виявлено, що показник поширеності хвороб серед населення Тернопільської області незначно зростав - 31809,6 у 2009 р. до 1844,1 на 1000 населення у 2013 р. $(+1,87 \%)$, а порівняно 3 2012 р. - на 1,26\% (1820,9 на 1000 населення). Показник поширеності захворювань за 2013 р. коливався від 1419,9 в Кременецькому, до 2146,8 в Монастириському районі. Вищі показники поширеності на 1000 населення від середньообласного спостерігалися у Монастириському 2146,8 , Підволочиському - 2055,9, Бучацькому 2020,7 , Бережанскому - 1995,9, Чортківському 1964,0 районах і м. Тернополі - 1935,1. Нижчі від середньообласного показника показники виявлено у Кременецькому - 1419,9, Козівському - 1584,9, Збаразькому - 1680,1 районах. Що стосується показника поширеності хвороб серед населення України, то він у даний період незначно зростав - 31846,3 у 2009 р. до 1856,5 на 1000 населення у 2013 р. (+0,55\%), а порівняно з 2012 р. - на 0,1\% (1854,6 на 1000 населення). Таким чином, зберігається проблема накопичення хронічної патології серед населення України.

Аналіз первинної захворюваності засвідчив незначне зниження ії рівня у Тернопільській області за вказаний період. По Україні в цілому в 2013 р. рівень первинної захворюваності знизився і в динаміці за п'ять років, і порівняно 3 попереднім роком (табл. 2). 
Таблиця 1. Поширеність захворювань у Тернопільській області та в Україні у 2009-2013 рр. (на 1000 населення)

\begin{tabular}{|l|c|c|c|c|c|}
\hline \multirow{2}{*}{ Адміністративна територія } & \multicolumn{5}{|c|}{$\begin{array}{c}\text { Показник поширеності захворювань } \\
\text { (на 1000 населення) }\end{array}$} \\
\cline { 2 - 6 } & 2009 p. & 2010 p. & 2011 p. & 2012 p. & 2013 p. \\
\hline Тернопільська область & 1809,6 & 1824,1 & 1816,1 & 1820,9 & 1844,1 \\
\hline Україна & 1846,3 & 1867,9 & 1870,9 & 1854,6 & 1856,5 \\
\hline
\end{tabular}

Таблиця 2. Первинна захворюваність населення Тернопільської області та України у 2009-2013 рр. (на 1000 населення)

\begin{tabular}{|c|c|c|c|c|c|}
\hline \multirow[t]{2}{*}{ Адміністративна територія } & \multicolumn{5}{|c|}{$\begin{array}{c}\text { Показник первинної захворюваності } \\
\text { (на } 1000 \text { населення) }\end{array}$} \\
\hline & $2009 \mathrm{p}$. & $2010 \mathrm{p}$. & $2011 \mathrm{p}$. & $2012 \mathrm{p}$. & 2013 p. \\
\hline Тернопільська область & 703,9 & 700,5 & 686,6 & 674,3 & 671,5 \\
\hline Україна & 718,7 & 722,6 & 7101,3 & 685,6 & 683,8 \\
\hline
\end{tabular}

Спостерігалося зменшення рівня первинної захворюваності серед населення Тернопільської області за період з 2009 по 2013 роки з 703,9 у 2009 р. до 671,5 на 1000 населення (-4,60\%). Найвищі показники первинної захворюваності у 2013 р. спостерігалися у Монастириському $(868,6)$, Бучацькому $(784,5)$, Підволочиському $(761,6)$ районах, найнижчий - у Козівському $(424,3)$ районі. Зменшення рівня первинної захворюваності серед всього населення України за останні п'ять років з 718,7 у 2009 р. до 683,8 на 1000 населення (-4,85\%), при зниженні їі значення порівняно з минулим роком з 685,6 до 683,8 на 1000 населення (-0,26\%), свідчить про стабілізацію тенденцій до зниження кількості вперше виявлених захворювань (-1,72\% у 2011 р., -3,46\% у 2012 р.).

Структура поширеності захворювань серед населення Тернопільської області за 2013 р. зображена на рисунку 1.
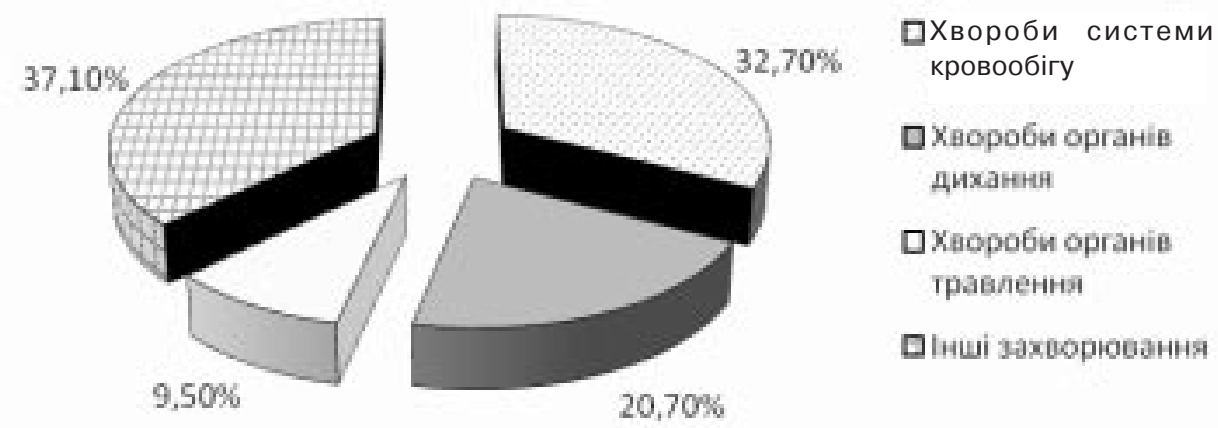

Рис. 1. Структура поширеності захворювань серед населення Тернопільської області (2013 р.)

Як видно з рисунку, у 2013 р. у структурі поширеності захворювань за класами хвороб перше місце посідають хвороби системи кровообігу - 603,1 на 1000 населення, що складає 32,7\%, у 2012 р. - 591,1 (32,5\%); друге - хвороби органів дихання - 381,4 (20,7\%), у 2012 р. - 376,4 $(20,7 \%)$; третє - хвороби органів травлення $175,8(9,5 \%)$, у 2012 р. - 172,1 (9,5\%).

Структура поширеності хвороб серед всього населення України за більшістю класів порівняно з попередніми роками суттєво не змінилася. Основу структури поширеності хвороб традиційно формують хвороби системи кровообігу $(31,47 \%)$, хвороби органів дихання $(19,32 \%)$, хво- роби органів травлення $(9,70 \%)$, хвороби сечостатевої системи $(5,43 \%)$, хвороби кістковом'язової системи та сполучної тканини (5,37\%), хвороби ока та його придаткового апарату (4,97\%), ендокринні хвороби, розлади харчування та порушення обміну речовин (4,84\%), хвороби шкіри та підшкірної клітковини (2,64\%), травми, отруєння та деякі інші наслідки дії зовнішніх чинників (2,63\%).

Показники поширеності хвороб за останні п'ять років (2009-2013 рр.) збільшилися за наступними класами: ендокринні хвороби, розлади харчування та порушення обміну речовин $(9,78 \%)$, новоутворення $(9,33 \%)$, хвороби системи кровообігу (3,83\%); менш виразно - за кла- 
сами хвороби ока та його придаткового апарату (1,96\%), хвороби сечостатевої системи (1,78\%); хвороби вуха та соскоподібного відростка $(1,73 \%)$.

Зниження показників поширеності хвороб зафіксовано за наступними класами: хвороби органів дихання (-5,96\%), розлади психіки та поведінки (-3,61\%), хвороби крові й кровотворних органів та окремі порушення із залученням імунного механізму (-2,87\%), травми, отруєння та деякі інші наслідки дії зовнішніх чинників $(-2,33 \%)$, хвороби нервової системи $(-2,02 \%)$.

У структурі первинної захворюваності населення Тернопільської області у 2013 р. перше місце посідають хвороби органів дихання - 304,5 на 1000 населення, що становить 45,4\%, у 2012 р. - 304,2 $(45,1 \%)$, друге місце - хвороби системи кровообігу - 48,8 (7,3\%), у 2012 р. - 48,2 (7,1\%), третє місце - хвороби шкіри та підшкірної клітковини 46,6 (6,9\%), у 2012 р. - 45,9 (6,8\%) (рис. 2).

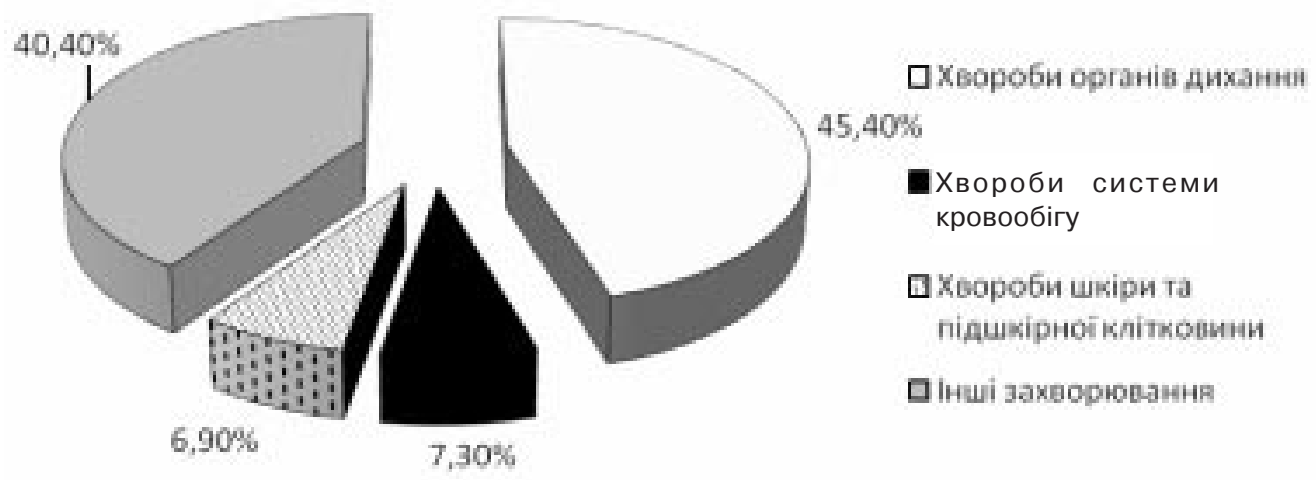

Рис. 2. Структура первинної захворюваності населення Тернопільської області (2013 р.)

Структуру первинної захворюваності населення України у 2013 р., як і в попередньому році, переважно формували: хвороби органів дихання (42,85\%), хвороби системи кровообігу (7,27\%), травми, отруєння та деякі інші наслідки дії зовнішніх чинників $(6,72 \%)$, хвороби сечостатевої системи $(6,60 \%)$, хвороби шкіри та підшкірної клітковини (5,98\%), хвороби ока та його придаткового апарату $(5,25 \%)$.

У цілому поширеність хвороб у Тернопільській області лише на 0,67\%, а первинна захворюваність - на 1,79\% нижча за середній показник по Україні. Невпинне зростання поширеності захворювань порівняно з 1991 р. (на 40,53\%) не лише підводить нас до питання підвищення доступності, якості та ефективності медичної допомоги, але й потребує розв'язання соціальноекономічних проблем, всебічного посилення профілактичних заходів, формування здорового способу життя населення та покращення якості його життя.

\section{Висновки}

1. Аналіз показників поширеності хвороб та первинної захворюваності протягом 2009-2013 років свідчить про негативні тенденції стану здоров'я населення. Відмічено зростання рівня поширеності хвороб протягом досліджуваного періоду та деяке зниження рівня первинної захворюваності.

2. Загальний показник поширеності хвороб серед населення Тернопільської області формувався за рахунок хвороб системи кровообігу $(32,7 \%)$, органів дихання $(20,7 \%)$ та травлення $(9,5 \%)$.

3. Структуру первинної захворюваності формували хвороби органів дихання $(45,4 \%)$, хвороби системи кровообігу (7,3\%), хвороби шкіри та підшкірної клітковини (6,9 \%).

Перспективи подальших досліджень полягають у подальшому спостереженні та вивчення основних показників захворюваності населення.

\section{Список літератури}

1. Основні показники стану здоров'я населення та ресурсів охорони здоров'я Тернопільської області / гол. ред. М. М. Буртняк. - Тернопіль, 2009. - 128 с.

2. Основні показники стану здоров'я населення та ресурсів охорони здоров'я Тернопільської області / гол. ред. М. М. Буртняк. - Тернопіль, 2011. - 127 с.

3. Основні показники стану здоров'я населення та ресурсів охорони здоров'я Тернопільської області / гол. ред. М. М. Буртняк. - Тернопіль, 2012. - 127 с.

4. Основні показники стану здоров'я населення та ресурсів охорони здоров'я Тернопільської області / гол. ред. М. М. Буртняк. - Тернопіль, 2013. - 127 с. 
5. Ціборовський О. М. Захворюваність як показник стану здоров'я населення України і основні ризики їі підвищення в сучасних історичних умовах (1991-2008рр.) / О. М. Ціборовський. - К., 2010. - 63 с.

6. Щорічна доповідь про стан здоров'я населення, санітарно-епідемічну ситуацію та результати діяльності системи охорони здоров'я України. 2013 рік / за ред. О. С. Мусія. - К., 2014. - 438 с.

\section{СРАВНИТЕЛЬНЫЙ АНАЛИЗ ОСНОВНЫХ ПОКАЗАТЕЛЕЙ ЗАБОЛЕВАЕМОСТИ НАСЕЛЕНИЯ ТЕРНОПОЛЬСКОЙ ОБЛАСТИ}

В.Л. Смирова, Н.Я. Панчишин, О.Н. Литвинова

ГВУЗ «Тернопольский государственный медицинский университет имени И.Я. Горбачевского МЗ Украины»

Цель: проанализировать изменения в заболеваемости населения Тернопольской области в течение 2009-2013 годов.

Материалы и методы. Наблюдение осуществлялось как популяционное, эпидемиологическое и охватывало период с 2009 до 2013 года. Были проанализированы статистические справочники и статистические данные относительно заболевания населения области.

Результаты. Установлено, что общий показатель распространенности болезней среди населения Тернопольской области формировался за счет болезней системы кровообращения (32,7\%), органов дыхания $(20,7 \%)$ и пищеварения (9,5\%). Структуру первичной заболеваемости формировали болезни органов дыхания $(45,4 \%)$, болезни системы кровообращения (7,3\%), болезни кожи и подкожной клетчатки (6,9\%).

Выводы. Анализ показателей распространенности болезней и первичной заболеваемости в течение 2009-2013 годов свидетельствует о негативных тенденциях состояния здоровья населения. Отмечен рост уровня распространенности болезней в течение исследуемого периода и некоторое снижение уровня первичной заболеваемости.

КЛЮЧЕВЫЕ СЛОВА: заболеваемость, распространенность болезней, сравнительный анализ.

\section{COMPARATIVE ANALYSIS OF THE BASIC INDICES OF MORBIDITY OF THE POPULATION OF TERNOPIL REGION}

V.L. Smirnova, N.Y. Panchyshyn, O.N. Lytvynova

SHEl "Ternopil State Medical University named after I. Gorbachevskyi Ministry of Health of Ukraine"

Purpose: to analyze changes in morbidity of the population of Ternopil region during 2009-2013.

Materials and methods. Observations was carried out as population, epidemiological and covered the period from 2009 to 2013. Statistical references and statistics on morbidity in region have been analyzed.

Results. It is established that the general prevalence index of diseases among population of Ternopil region formed due to cardiovascular diseases $(32,7 \%)$, respiratory $(20,7 \%)$ and digestive system $(9,5 \%)$. Structure of primary morbidity formed respiratory diseases (45,4\%), cardiovascular diseases $(7,3 \%)$, skin diseases and subcutaneous tissue $(6,9 \%)$.

Conclusions. The analysis of disease prevalence and primary morbidity during $2009-2013$ indicates the negative tendencies of population state of health. Increase of prevalence level of diseases during the study period and some reduction in level of primary disease has been marked.

KEY WORDS: morbidity, prevalence of diseases, comparative analysis.

\section{Відомості про авторів:}

Рукопис надійшов до редакції 05.11.2014 p.

Смірнова Валентина Леонідівна - к.мед.н., доц. кафедри соціальної медицини, організації та економіки охорони здоров'я з медичною статистикою ДВНЗ «Тернопільський державний медичний університет імені І.Я. Горбачевського МОЗ України»; тел.: +38(0352)-52-72-33.

Панчишин Наталія Ярославівна - к.мед.н., доц. кафедри соціальної медицини, організації та економіки охорони здоров'я з медичною статистикою ДВНЗ «Тернопільський державний медичний університет імені І.Я. Горбачевського МОЗ України»; тел.: +38(0352)-52-72-33.

Литвинова Ольга Несторівна - к.мед.н., доц. кафедри соціальної медицини, організації та економіки охорони здоров'я з медичною статистикою ДВНЗ «Тернопільський державний медичний університет імені І.Я. Горбачевського МОЗ України»; тел.: +38(0352)-52-72-33. 